\title{
Effect of AM fungus (Glomus macrocarpum) with additional phosphate fertilization on biomass yield nutrient uptake in two Basellaceae plants; Basella alba L. and Basella cordifolia L.
}

Kamble S.S. ${ }^{1}$ and H.C Lakshman ${ }^{2 *}$

1P.G. Department of studies in Botany, Shivaji University, Kolhapur - 416004, Maharashtra, India.

2P.G. Department of studies in Botany, Karnataka University, Dharwad, Karnataka, India.

Received: February 4, 2017; Accepted: February 21, 2017

\begin{abstract}
Inoculation of AMF (Arbuscular mycorrhizal fungus) (Glomus macrocarpum (AMF) with additional, super phosphate and rock phosphate treatment showed varied results on Basella alba and Basella cordifolia. At 30 days interval, experimental plants have not exhibited any better growth or nutrient uptake in mycorrhizal plants nor non-mycorrhization plants. However, both the plants significantly showed higher growth, biomass production nutrients uptake in both shoot and root of mycorrhizal plants over non-mycorrhizal plants. When the plants of Basella alba treated with $3.0 \mathrm{mg}$ rock phosphate/ $\mathrm{kg}$ soil, with mycorrhizal inoculation. But, Basella cordifolia showed plants treated with $1.0 \mathrm{mg}$ super phosphate $/ \mathrm{kg}$ soil with mycorrhizal inoculation improved plant growth biomass. On contrast to this per cent of AM fungal colonization and spore number decreased with the increased dosage of Super phosphate than those received rock phosphate.
\end{abstract}

Key words: Glomus macrocarpum; Basella alba L.; Basella cordifolia L.; Super phosphate and Rock phosphate.

\section{Introduction}

Proper fertilizer application is an essential method to increase plant, production that can be used on infertile soils. Most of the Indian tropical soils lack required phosphorus to many types of plants (Nambiar, 2002). It has been well documented that Arbuscular mycorrhizal fungi (AMF) are the members of Phycomycetes associated with most of the terrestrial plants play vital role in uptake and translocation of diffusion limited nutrients mainly ' $\mathrm{P}$ ' there by promote plant growth (Koide et al., 2004, Lakshman, 2009). The beneficial effect of AM fungi had a special importance, for those plants having coarse and poorly branched root systems. Since AM fungi external hyphae can extend as much as $5-8 \mathrm{~cm}$ away from the roots, absorb nutrients from a much larger soil volume than the absorption zone surrounding the non-mycorrhizal root system (Lakshman, 1996; Gai et al., 2006). And thus absorption of phosphate ions could possible through some beneficial micro symbionts that are associated with rhizospheric zones of numerous plants. It is Arbuscular mycorrhizal fungi have associated symbolically almost all types of plants including medicinal plants. In many instances, when nutrients are exhausted from the soil, a balanced fertilizer will be necessity in order to maintain nutrient balance in mycorrhizal fungi especially important for the absorption of nutrients of low mobility in soil solution such as $\mathrm{P}, \mathrm{K}, \mathrm{M}, \mathrm{Zn}, \mathrm{Fe}$ and $\mathrm{Cu}$ etc. It was suggested that $\mathrm{P}$ is usually absorbed in the form of orthophosphate and transported actively through the much-branched hyphae as polyphosphate (Nye and Kirk, 1987; Vaast et al., 2006; Bagyaraj, 2006).

The major transfer of ' $\mathrm{P}$ ' from the AM fungi to the plants occurred in those roots colonized with Arbuscular mycorrhizal main components called arbuscules. And thus P transfer from the fungus to the host plants takes place in

\section{${ }^{*}$ Corresponding Author:}

Dr. H. C. Lakshman,

Professor and Former Chairman,

P.G.Department of Studies in Botany, Karnatak University,

Dharwad- 580 003, Karnataka, India.

E-mail: dr.hclakshman@gmail.com a process of interchange with carbon compound metabolites. It has been observed that, $80-85 \%$ of total applied $\mathrm{P}$ is not available to plants because of their inaccessibility, fixation and immobilization. In this context, many experiments have been proved that, AM fungal inoculation increase the recovery of phosphate fertilization from soil.

Researches on AM fungi dependence of many plants have clearly demonstrated that tropical crops will not grow well in low P soils without an effective mycorrhizal association (Redhead, 1971; Rhodes and Gerdeman, 1978; Joner and Jakobsen, 1995). Since mycotrophic plants depend on AM fungal colonization when they grown under low external $\mathrm{P}$ conditions, their yield can be enhanced by increasing efficiency of Arbuscular mycorrhizal fungi, either by inoculation of more efficient fungal strains or by fungi through the use of agronomic practices. But, less report are available on phosphate fertilizer application on medicinal plants to know their effect along with mycorrhizal inoculation. The present study investigated the effects of the different levels of super phosphate and rock phosphate on two vegetable plants with and without inoculation of AM fungus (Glomus macrocarpum) was investigated.

\section{Materials and Methods}

The seeds of experimental plants (Basella alba and Basella cordifolia) were sown in $15 \times 20 \mathrm{~cm}$ diameter earthen pots containing four $\mathrm{kg}$ of sterilized phosphorus deficient soil. The soil was mixed in 1:1 proportion (1 part of garden soil and 1 part of pure sand). The Physico-chemical characteristic of this soil was analyzed given in (Table. 1). The random black designed triplicate sets of pots were maintained with proper controls. Finally, three different levels of super phosphate and rock phosphate at the rate of

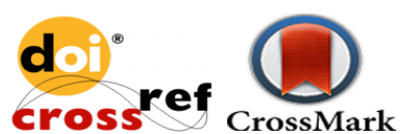


1.0, 1.5 and $3.0 \mathrm{mg} / \mathrm{kg}$ were added to each experimental pot, except control pots. $15 \mathrm{gm}$ of AM fungal inoculum (Glomus macrocarpum) consists of freshly infected chopped root pieces, spores, sporocarps, mycelia and rhizospheric soil collected from the rhizospheric soil of host plant Sorghum sudanense was maintained without contamination pests or insects. The inoculum was placed $4 \mathrm{~cm}$ below the surface each experimental pots before sowing the seeds. To maintain the moisture, content the experimental pots were watered on every alternate day. All the pots were maintained in green house. The following treatments were given for each experimental plant.

1. Non-mycorrhizal plant (Control)

2. Three levels of Rock phosphate + AM fungus (Glomus macrocarpum)

3. Three levels of Super phosphate + AM fungus (Glomus macrocarpum)

Periodical data were recorded for three harvests in between thirty days intervals. The observations were recorded on the plant height, dry weight of shoot and root are recorded at every interval of 30 days, and AM fungal spores were isolated by the wet-sieving and decanting method following (Gerdeman and Nicholson, 1963). Per cent of AM fungal colonization of roots were estimated according to (Philips and Hayman, 1970). Phosphorus content in plant was determined calorimetrically by the vanadomolybdate/phosphoricyellow colour method outlined by Jackson (1973). Total nitrogen content was determined by the Microkjeldahl method (Bremmer, 1960). Potassium was estimated by Flame Photometer following the procedure of Chapman and Pratt (1961). Other Physico-chemical analysis of the Soil used for experimental pots like $\mathrm{pH}$, Moisture content was estimated according to the procedures of Jackson (1973). Different levels of rock phosphate and super phosphate were mixed in distilled water and provided to each of the experimental plants by using 1.0, 1.5 and $3.0 \mathrm{mg} / \mathrm{kg}$ soil/pot.

\section{Results}

The AM fungus (Glomus macrocarpum) inoculated plants grew much taller than the non-mycorrhizal ones with $\mathrm{P}$ fertilizer application in both of the experimental plants (Tables 2-3). The highest plant height $(46.5 \mathrm{~cm})$ was observed in Basella alba when treated with $3.0 \mathrm{~g} \mathrm{RP} / \mathrm{kg}$ soil, whereas, Basella cordifolia showed growth $(55.1 \mathrm{~cm})$ when treated with $1.0 \mathrm{mg} \mathrm{SP} / \mathrm{kg}$ soil with AM fungal inoculation. The plants showed increased plant height, shoot dry weight, per cent colonization and spore number with gradual increased application of rock phosphate dosages. But gradual increased per cent root colonization with increased spore number was not noticed in Basella alba with increased Super phosphate fertilization. So, the relation between per cent colonization and spore number was seen only in Basella cordifolia treated with rock phosphate fertilizer.

The super phosphate fertilization experiments were not similar to these of rock phosphate treated experiments; it was observed that the application RP level $1.0 \mathrm{mg}$
$\mathrm{SP} / \mathrm{kg}$ soil greatly influenced the plant height and biomass production in AM fugal inoculated experimental plants. These plants showed decreased percent colonization and spore number with increased SP levels in both Basella alba and Basella cordifolia. Nutrient uptake (NPK) was determined in the shoots of mycorrhizal and non-mycorrhizal of both the experimental plants. The results revealed that the increased higher concentration of $\mathrm{N}, \mathrm{P}, \mathrm{K}$ was determined in all the experimental plants, only after the AM fungal (Glomus macrocarpum) inoculation. These significant results were obtained in both rock phosphate and super phosphate treatments (Table 2 and 3). Rootshoot ratio was drastically increased in all the noninoculated plants over the mycorrhizal plants. The $\mathrm{P}$ fertilizer application on experiments indicated that mycorrhizal inoculation alone aids in the effective utilization of rock phosphate than the super phosphate. This is because of changing them into available form by AM fungi, which was later taken up by the plants for their better growth and development.

\section{Discussion}

Some soil microorganisms play vital role in solubilization of mineral compounds which later on mobilized by the production of organic acids, but many microorganisms can bring the insoluble inorganic compounds into solution form. In such cases, arbuscular mycorrhizal fungi cearly produce an increase in absorbing root surface area clue to gross changes in morphology of the feeder roots (Hayman and Mosse, 1972; Manjunath and Bagyaraj, 1984; Me Gonigle et al., 1990; Sandeepkumar and Lakshman, 2010; Lakshman, 2014). The data obtained in the present study after positive indications that the mycorrhizal colonization of the host plants, these two vegetable plants were able to utilize quickly soluble phosphates. The super phosphate treatments were more efficient in Basella cordifolia. These two plants demonstrated greater growth and shoot dry weight and mineral uptake in their shoots. Although the decrease in number of chlamydospores associated with increased super phosphate fertilization was not statistically significant. The trend of lower per cent mycorrhizal colonization with increasing fertilizer (SP) agrees with the results of previous workers (Sylvia and Schenck, 1983; Sieverding and Howler, 1985). On the other hand, arbuscular mycorrhizal fungi are known to occur in soils with very high P contents (Davis et al., 1984; Powel and Daniel, 1978) and thus among the species of mycorrhizal fungi there may be different response to low or high soil P conditions or to P fertilisation treatments (Jones, 2000; Pattinson et al., 2004).

Studies on Basella alba treated with $3.0 \mathrm{mg}$ rock phosphate $/ \mathrm{kg}$ soil dosages had the beneficial response to mycorrhiza (Glomus macrocarpum). The plants grow much, greater than non-mycorrhizal plants. This could be attributed that low solubility of $\mathrm{P}$ source (rock phosphate) is slowly diffuse in to the soil and mycorrhizal hyphae slowly absorb available $\mathrm{P}$ more effective than the plants treated with super phosphate. 
Plant roots may increase the rate of dissolution of rock phosphate by lowering the concentration of $\mathrm{P}$ in the soil solution and in some instances by lowering the $\mathrm{pH}$ of the soil. All the three levels of rock phosphate with mycorrhizal inoculation showed increased plant height, total dry weight of shoot in Basella alba. Thus, the treatment of AM fungus $+(3.0 \mathrm{mg} / \mathrm{kg}$ soil $)$ rock phosphate was most effective in promoting plant growth. These studies indicated that mycorrhizal inoculation helps in the effective utilization of rock Phosphate by changing it into available form, which later is taken up by the plants for their better growth and development. These findings are in consistent with the earlier worker's contributions (Jalali and Thereja, 1985 Pacovsky et al., 1986). But, the super phosphate on Basella cordifolia revealed, that the mycorrhizal inoculation with $1.0 \mathrm{mg}$ super phosphate $/ \mathrm{kg}$ soil was most effective than the other two levels of fertilizer application as seen in Basella Species.

Plants inoculated with AM fungus (Glomus macrocarpum) and treated with different levels of super phosphate and plants treated with phosphate grown in green house conditions showed enhanced nutrients concentration in shoots, compared to non-inoculated plants. These findings are supported by others who reported similar results (Ross, 1971 Powell and Daniel, 1978; Harley and Smith, 1983; Vaast et al., 1996). There were significantly increased root-shoot ratios in non-mycorrhizal plants over the mycorrhizal plants. These findings are par with the results obtained by early works of (Redhead, 1977; Kormanik el al., 1977; Mosse, 1990). The fraction of P applied that is absorbed by the plant after mycorrhizal inoculation is considered to the density of roots in the soil (Smith, 1982). At a lower soil P buffer capacity, the effect of root uptake on the rate of dissolution should be greater. Many rhizospheric soils contain organic acids with low calcium, it could be desirable to practice AM fungal inoculation technique to young nursery plants with different 'levels of rock phosphate and indigenous mycorrhizal fungi. It may be concluded that mycorrhizal plants absorb ' $\mathrm{P}$ ' only from the soluble ' $\mathrm{P}$ ' pools in the soil and that they are unable to utilize source of ' $\mathrm{P}$ ' that are unavailable to non-mycorrhizal roots. Results presented here for spore density and root colonization are in agreement with these found in the green house and the field showing that AM fungal species, host plant species and soil conditions have been reported to effect on mycorrhizal formation and sporulation in pot culture (Brundrett et al., 1996). Phosphorus with mycorrhiza responses for the plant growth agreed with that reported for other plants grown in controlled environment (Youpensuk et al., 2005), there by confirming mycorrhizal nutritional benefits that the strong interrelationship between $\mathrm{P}$ supply and mycorrhizal response under nutrient stressed conditions.

Table 1: Physico-chemical properties of soil used for pot experiments.

\begin{tabular}{ll}
\cline { 2 - 2 } \multicolumn{1}{c}{ Characteristics } & Values \\
\cline { 2 - 3 } Soil moisture (1\%) & 2.63 \\
$\mathrm{pH}$ & $6.9 \%$ \\
Organic matter (1 \%) & $0.63 \%$ \\
E.C milli mhos & $0.47 \%$ \\
Nitrogen & $18.12 \%$ \\
Phosphorus & $14.3 \%$ \\
Potassium & $26.5 \%$ \\
Iron & $29.2 \%$ \\
Zinc & $6.51 \%$ \\
Copper & $4.7 \%$ \\
Magnesium & $3.51 \%$ \\
\hline
\end{tabular}

Each value is the mean of 12 samples

Table 2: Effect of different P levels with AM fungus (Glomus macrocarpum) inoculated, Basella alba L. for 30,60,90 days.

\begin{tabular}{|c|c|c|c|c|c|c|c|c|c|c|c|c|}
\hline \multirow{2}{*}{$\begin{array}{c}\text { Duration } \\
\text { Treatments }\end{array}$} & \multirow{2}{*}{$\begin{array}{c}\text { Plant } \\
\text { height } \\
(\mathrm{cm})\end{array}$} & \multirow{2}{*}{$\begin{array}{l}\text { Dry wt of } \\
\text { shoot (g) }\end{array}$} & \multirow{2}{*}{$\begin{array}{l}\text { Dry wt of } \\
\text { root }(g)\end{array}$} & \multirow{2}{*}{$\begin{array}{c}\text { Root } \\
\text { /shoot } \\
\text { ratio \% }\end{array}$} & \multirow{2}{*}{$\begin{array}{l}\text { \% VAM } \\
\text { colloni- } \\
\text { zation }\end{array}$} & \multirow{2}{*}{$\begin{array}{c}\text { Spore } \\
\text { na/50g } \\
\text { soil }\end{array}$} & \multicolumn{4}{|c|}{ Shoot } & \multicolumn{2}{|c|}{ root } \\
\hline & & & & & & & N\% & $\mathrm{P} \%$ & $\mathbf{K} \%$ & N\% & $\mathbf{P} \%$ & $\mathbf{K} \%$ \\
\hline \multicolumn{13}{|c|}{ For 30 days } \\
\hline NM & $11.0 \pm 1.0$ & $0.91 \pm 10$ & $0.71 \pm 0.0$ & $0.78 \pm 0.0$ & - & - & $1.32 \mathrm{~b}$ & $0.09 \mathrm{e}$ & $1.15 \mathrm{c}$ & $0.41 \mathrm{~d}$ & $0.05 \mathrm{f}$ & $0.42 \mathrm{~d}$ \\
\hline $\mathrm{M}+\mathrm{RP} 1$ & $12.3 \pm 2.0$ & $1.65 \pm 1.0$ & $0.81 \pm 0.0$ & $0.49 \pm 0.0$ & $49.6 \pm 2.1$ & $50.7 \pm 21$ & $1.42 \mathrm{~b}$ & $0.15 \mathrm{e}$ & $2.13 \mathrm{~b}$ & $0.75 \mathrm{a}$ & $007 \mathrm{e}$ & $0.61 \mathrm{c}$ \\
\hline $\mathrm{M}+\mathrm{RP} 2$ & $21.5 \pm 2.0$ & $1.73 \pm 1.0$ & $0.90 \pm 1.0$ & $0.52 \pm 0.0$ & $52.5 \pm 3.1$ & $50.4 \pm 1.1$ & $1.74 \mathrm{a}$ & $0.18 \mathrm{~d}$ & $2.30 \mathrm{a}$ & $0.32 \mathrm{e}$ & $0.11 \mathrm{~d}$ & $0.35 c$ \\
\hline $\mathrm{M}+\mathrm{RP} 3$ & $29.8 \pm 2.1$ & $2.11 \pm 1.0$ & $1.20 \pm 0.0$ & $0.57 \pm 0.0$ & $54.5 \pm 1.0$ & $60.2 \pm 3.1$ & $2.11 \mathrm{a}$ & $0.22 \mathrm{a}$ & $2.41 \mathrm{~b}$ & $0.91 \mathrm{a}$ & $0.12 \mathrm{~d}$ & $1.25 \mathrm{a}$ \\
\hline $\mathrm{M}+\mathrm{SPl}$ & $35.1 \pm 2.0$ & $2.80 \pm 0.0$ & $0.91 \pm 0.0$ & $0.53 \pm 0.0$ & $38.5 \pm 2.1$ & $49.2 \pm 2.1$ & $1.21 \mathrm{~b}$ & $0.22 \mathrm{a}$ & $2.54 \mathrm{a}$ & $0.32 \mathrm{e}$ & $0.00 \mathrm{~d}$ & $0.95 \mathrm{a}$ \\
\hline $\mathrm{M}+\mathrm{SP} 2$ & $29.1 \pm 2.0$ & $2.10 \pm 0.0$ & $0.80 \pm 0.0$ & $0.73 \pm 0.0$ & $36.3 \pm 2.2$ & $42.5 \pm 3.1$ & $0.83 \mathrm{~d}$ & $0.21 \mathrm{~b}$ & $2.41 \mathrm{~b}$ & $0.51 \mathrm{c}$ & $0.04 \mathrm{f}$ & $0.45 \mathrm{c}$ \\
\hline $\mathrm{M}+\mathrm{SP} 3$ & $28.5 \pm 1.0$ & $2.62 \pm 0.0$ & $0.83 \pm 0.0$ & $0.32 \pm 0.0$ & $35.2 \pm 1.0$ & $47.2 \pm 1.1$ & $0.96 \mathrm{~b}$ & $0.23 \mathrm{a}$ & $2.52 \mathrm{a}$ & $0.49 \mathrm{c}$ & $0.07 \mathrm{e}$ & $0.58 \mathrm{~b}$ \\
\hline \multicolumn{13}{|c|}{ For 60 days } \\
\hline NM & $13.1 \pm 1.0$ & $1.02 \pm 0.0$ & $0.73 \pm 0.5$ & $0.78 \pm 0.0$ & - & - & $1.32 \mathrm{~b}$ & $0.11 \mathrm{e}$ & $1.18 \mathrm{e}$ & $0.52 \mathrm{~d}$ & $0.08 \mathrm{e}$ & $0.51 \mathrm{c}$ \\
\hline $\mathrm{M}+\mathrm{RP} 1$ & $18.3 \pm 2.1$ & $1.70 \pm 1.0$ & $1.85 \pm 0.0$ & $0.50 \pm 0.0$ & $51.4 \pm 2.1$ & $53.4 \pm 21$ & $1.61 \mathrm{~b}$ & $0.18 \mathrm{~d}$ & $2.17 \mathrm{~b}$ & $0.79 \mathrm{~b}$ & $0.10 \mathrm{a}$ & $0.71 \mathrm{c}$ \\
\hline $\mathrm{M}+\mathrm{RP} 2$ & $35.1 \pm 3.1$ & $1.91 \pm 1.0$ & $0.94 \pm 1.0$ & $0.45 \pm 0.0$ & $54.5 \pm 3.1$ & $57.3 \pm 11$ & $1.83 \mathrm{~b}$ & $0.21 \mathrm{c}$ & $2.34 \mathrm{a}$ & $0.84 \mathrm{a}$ & $0.10 \mathrm{a}$ & $1.11 \mathrm{~b}$ \\
\hline $\mathrm{M}+\mathrm{RP} 3$ & $40.2 \pm 2.2$ & $3.30 \pm 0.0$ & $1.23 \pm 0.0$ & $0.39 \pm 0.0$ & $55.4 \pm 2.0$ & $62.5 \pm 2.1$ & $2.21 \mathrm{a}$ & $0.23 \mathrm{a}$ & $2.94 \mathrm{a}$ & $1.11 \mathrm{a}$ & $0.15 \mathrm{a}$ & $1.51 \mathrm{a}$ \\
\hline $\mathrm{M}+\mathrm{SPl}$ & $42.1 \pm 1.1$ & $3.15 \pm 0.0$ & $0.37 \pm 0.0$ & $0.37 \pm 0.0$ & $36.3 \pm 1.1$ & $47.4 \pm 1.1$ & $1.42 \mathrm{~b}$ & $0.20 \mathrm{c}$ & $2.61 \mathrm{a}$ & $0.75 b$ & $0.07 \mathrm{~d}$ & $1.32 \mathrm{~b}$ \\
\hline $\mathrm{M}+\mathrm{SP} 2$ & $31.5 \pm 1.0$ & $2.09 \pm 1.0$ & $0.73 \pm 0.0$ & $0.61 \pm 0.0$ & $35.5 \pm 2.1$ & $41.5 \pm 2.1$ & $0.91 \mathrm{c}$ & $0.22 \mathrm{~b}$ & $1.58 \mathrm{~b}$ & $0.51 \mathrm{~d}$ & $0.05 \mathrm{~d}$ & $0.52 \mathrm{~d}$ \\
\hline$. \mathrm{M}+\mathrm{SP} 3$ & $41.2 \pm 2.0$ & $3.11 \pm 1.0$ & $0.90 \pm 0.0$ & $0.30 \pm 0.0$ & $35.4 \pm 1.0$ & $45.3 \pm 3.5$ & $1.11 \mathrm{c}$ & $0.24 \mathrm{a}$ & $2.63 \mathrm{a}$ & $0.63 \mathrm{~d}$ & $0.09 \mathrm{~b}$ & $0.67 \mathrm{~b}$ \\
\hline \multicolumn{13}{|c|}{ For 90 days } \\
\hline NM & $15.1 \pm 1.0$ & $1.10 \pm 10$ & $0.72 \pm 0.0$ & $0.78 \pm 0.0$ & - & - & $1.41 \mathrm{~b}$ & $0.11 \mathrm{~d}$ & $1.41 \mathrm{~d}$ & $0.56 \mathrm{~d}$ & $0.07 \mathrm{~d}$ & $0.58 \mathrm{c}$ \\
\hline $\mathrm{M}+\mathrm{RP} 1$ & $21.2 \pm 1.0$ & $1.81 \pm 1.0$ & $0.52 \pm 1.0$ & $0.50 \pm 1.0$ & $51.2 \pm 1.0$ & $54.5 \pm 3.1$ & $1.82 \mathrm{~b}$ & $0.31 \mathrm{c}$ & $2.19 \mathrm{c}$ & $0.09 \mathrm{e}$ & $0.12 \mathrm{a}$ & $0.95 \mathrm{a}$ \\
\hline $\mathrm{M}+\mathrm{RP} 2$ & $40.2 \pm 2.1$ & $2.10 \pm 0.0$ & $1.00 \pm 0.0$ & $0.48 \pm 0.0$ & $55.4 \pm 3.0$ & $58.3 \pm 2.1$ & $1.93 \mathrm{a}$ & $0.34 \mathrm{~b}$ & $2.45 b$ & $0.95 b$ & $0.13 a$ & $1.41 \mathrm{a}$ \\
\hline $\mathrm{M}+\mathrm{RP} 3$ & $45.3 \pm 3.2$ & $3.60 \pm 1.0$ & $1.32 \pm 0.0$ & $0.37 \pm 0.0$ & $59.3 \pm 2.1$ & $67.4 \pm 3.1$ & $2.31 \mathrm{a}$ & $0.38 \mathrm{a}$ & $3.12 \mathrm{a}$ & $1.21 \mathrm{a}$ & $0.19 \mathrm{a}$ & $1.72 \mathrm{a}$ \\
\hline $\mathrm{M}+\mathrm{SPl}$ & $46.5 \pm 2.1$ & $3.15 \pm 1.0$ & $1.40 \pm 0.0$ & $0.29 \pm 1.0$ & $35.5 \pm 1.0$ & $45.3 \pm 2.1$ & $1.62 \mathrm{a}$ & $0.32 \mathrm{a}$ & $2.71 b$ & $0.82 b$ & $0.11 \mathrm{a}$ & $1.51 \mathrm{a}$ \\
\hline $\mathrm{M}+\mathrm{SP} 2$ & $32.0 \pm 1.0$ & $1.80 \pm 0.0$ & $0.90 \pm 0.0$ & 0.5040 .0 & $33.4 \pm 0.0$ & $41.2 \pm 1.1$ & $1.11 \mathrm{c}$ & $0.25 \mathrm{~b}$ & $2.80 \mathrm{~b}$ & $0.53 \mathrm{~d}$ & $0.09 \mathrm{~b}$ & $0.65 b$ \\
\hline $\mathrm{M}+\mathrm{SP} 3$ & $42.5 \pm 1.1$ & $3.40 \pm 3.44$ & $1.25 \pm 0.0$ & $0.36 \pm 1.0$ & $31.7 \pm 1.0$ & $43.1 \pm 2.1$ & $1.31 \mathrm{~b}$ & $0.31 \mathrm{a}$ & $2.94 \mathrm{a}$ & $0.74 c$ & $0.07 \mathrm{c}$ & $0.81 \mathrm{~b}$ \\
\hline $\begin{array}{l}\mathrm{NM}=\mathrm{No} \\
\text { of soil, } \mathrm{M} \\
\text { is the me }\end{array}$ & coma & 1701 & 1.011 & 1 & 年 & 政 & 然 & $\mathrm{RP} / \mathrm{kg}$ & $M+P D$ & $-4 M$ & $+3.0 \mathrm{~m}$ & $\begin{array}{l}\mathrm{P} / \mathrm{kg} \\
\text { value }\end{array}$ \\
\hline
\end{tabular}


Table 3: Effect of different P levels with AM fungus (Glomus macrocarpum) inoculated, Basella cordfolia L. for 30,60,90 days.

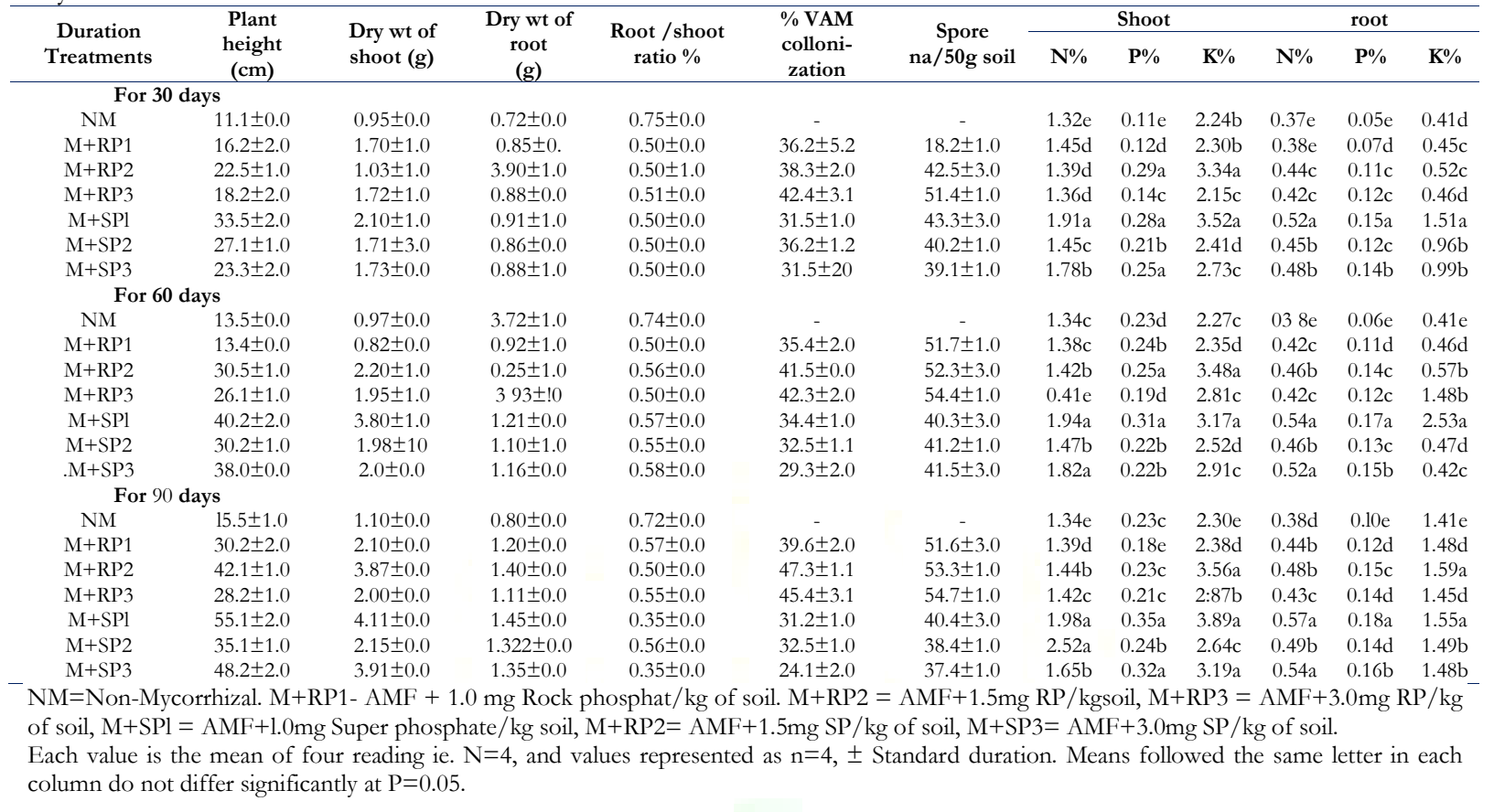

\section{References}

1. Brundrett M, Rougher N, Dell B, Grove T and Malajczuk $\mathrm{N}$. "Working with mycorrhizas in forestry and agriculture. ACIAR monograph". 32, ACIAR, Canberra, Australia, (1996): 374

2. Gai JP, Christie P, Feng G and Li XL. Twenty years of research on community composition and species distribution of arbuscular mycorrhizal fungi. Mycorrhiza, 16(2006): 229-239.

3. Joner EJ and Jakobsen I. Growth and extracellular phosphatase activity of Arbuscular mycorrhizal hyphae as influenced by soil organic matter. Soil Biol. Biochem, 27(1995): 1153-1159.

4. Koide RT and Mosse B. A history of research on arbuscular mycorrhiza. Mycorrhiza, 14(2004): 145-163.

5. Lakshman HC. Strategy for the production of colonized root based AM fungal inoculum for Basella rubra $\mathrm{L}$. Research Scholar. 4.2(2014): 37-43.

6. McGonigle TP, Evans DG and Miller MH. Effect of degree of soil disturbance on mycorrhizal colonization and phosphorus absorption by maize in growth chamber and field experiment. New Phytol, 116(1990): 629-636.

7. Pacovsky RS, Bethlenfalvay GJ and Paul EA. Comparisons between P-fertilized and mycorrhizal plants. Crop Sci, 26(1986): 151-156.
8. Pattinson GS, Hammill KA, Sutton BG and McGee PA. Growth and survival of seedlings of native plants in an improverished and highly disturbed soil following inoculation with arbuscular mycorrhizal fungi. Mycorrhiza, 14(2004): 339-346.

9. Sandeepkumar K and Lakshman HC. Effect of AM fungus and balanced phosphate fertilization on two fibre yielding plants, Corchorus capsularis (Jute) and Gossypium arboretum L. (Cotton). Nat. Enviorn. Poll. Tech. 9.2 (2010.): 305-309.

10. Vast PH, Zasoski RJ, and Bledsoe CS. Effect of Vesiculararbuscular mycorrhizal inoculation at different soil $\mathrm{P}$ availabilities on growth and nutrient uptake of invitro propagated Coffee (Coffea arabica L.) plants. Mycorrhiza, 6(1996):493-497.

11. Youpensuk S, Rerkasem B, Dell B and Lumyoung S. Effect of Arbuscular mycorrhizal fungi follow enriching tree (Macaranga denticulata). Fungal. Divers, 18(2005):189199

\section{Cite this article as:}

Kamble SS and Lakshman HC. Effect of AM fungus (Glomus macrocarpum) with additional phosphate fertilization on biomass yield nutrient uptake in two Basellaceae plants; Basella alba L. and Basella cordifolia L. Annals of Plant Sciences 6.03 (2017): 1590-1593. DOI: http://dx.doi.org/10.21746/aps.2017.03.003

Source of support: Nil.

Conflict of interest: Nil 